\title{
Biosurfactant Production and Biodesulphurization: Integrated Approach for Fuel Processing
}

\author{
Rajni Sharma ${ }^{1}$, Jagdish Singh ${ }^{2}$ and Neelam Verma ${ }^{1 *}$ \\ ${ }^{1}$ Department of Biotechnology, Punjabi University, India \\ ${ }^{2}$ Department of Biotechnology, Mata Gujri College, India
}

Submission: June 13, 2017; Published: July 26, 2017

*Corresponding author: Neelam Verma, Department of Biotechnology, Punjabi University, Patiala-147002, Punjab, India, Tel: +91-175-3046262(0)/+91-175-2285708(R); Fax: +91-175-2283073; Email: verma.neelam2@gmail.com

\begin{abstract}
The ever-growing global energy demand inflicts the incessant fuel supply at affordable rate. The energy from fossil fuels comprises a major (85\%) fraction of energy source, though the stocks of these fuels are being depleted and leading energy crisis. It is estimated about 2-4 trillion barrels of crude oil remain entrapped within the reservoirs due to its very high viscosity. Bio surfactants, the microbial products help to improve the mobility of oil by reducing the viscosity and capillary forces retaining the oil inside the reservoir. Biosurfactants being stable at extreme conditions of temperature, $\mathrm{pH}$ and salinity simulating the reservoir environment are the important tools for microbial enhanced oil recovery. These molecules have potential to replenish the depleting reservoirs with tremendous quantity of entrapped oil. On the other hand, supply of sulphur-free fuel is crucial for refineries to combat the pollution problem and to meet the stringent environmental regulations. Sulphur dioxide released from the burning of sulphur laden fuel leads to acid rain and air pollution. In the current scenario, Biodesulphurization (BDS) is a fascinating approach capable of removing complex compounds under mild conditions. The addition of surfactants was found to enhance the BDS rate by improving the solubility of organic compounds to the aqueous media and facilitating the microbes to get better access. Further, the desulphurized products can be converted into the surfactant-like substances subsequently enhancing BDS activity. These two different lines of action, bio surfactant production and bio desulphurization, can work in the integrated manner to improve the recovery of oil and its desulphurization which will reduce the burden from refineries and cut down the operational cost without compromising the environmental safety.
\end{abstract}

Keywords: Biosurfactant; Biodesulphurization; MEOR; Fuel; Energy; Refineries

\section{Introduction}

The global energy demand has been increased due to intense population growth, industrialization and high standard of living For hundreds of years, fossil fuels have remained the core source of energy and will still remain for many years despite the contribution from other alternative sources like biodiesel, geothermal energy and solar energy [1]. Nevertheless, the recent studies exposed the decline in oil production in some parts of the world due to oilfield maturity and it is difficult to discover new oil fields as an alternative to the exploited oil fields [2].

It is amazing to know that nearly 2-4 trillion barrels of crude oil remain in the reservoirs worldwide after the application of traditional recovery methods due to inability of oil to move out of the rocks due to high viscosity and interfacial tension $[3,4]$. To recover more oil from the existing and dumped oil fields, attention has been focused on the enhanced oil recovery (EOR) techniques like steam injection, polymer flooding, surfactant flooding or in situ combustion. However, these techniques are highly expensive, high energy demanding, hazardous and environment polluting. Therefore, the use of microbes and their metabolites for the improvement of the oil recovery is an excellent alternate and established as Microbial enhanced oil recovery-MEOR [5]. Biosurfactants are the significant tools for MEOR as these are competent to lower surface tension, viscosity, interfacial tension as well as capillary forces holding the oil within the reservoir. Henceforth, the biosurfactants facilitate the oil recovery by improving the oil mobilization out of the reservoir by forcing it to pump outward [6]. These molecules are produced by a vast variety of microbes (bacteria, yeast and fungi) [7-9]. 
Conversely, the removal of sulphur from the fuels is mandatory to meet environment legislations. A sulfur limit of $10-15 \mathrm{ppm}$ in crude oil was espoused by most of the developed countries while, in India, a sulfur limit of 50ppm is adopted in the metropolitan cities since 2010 [10]. The exploitation of sulphur containing fuel entails rigorous health and environment threats including respiratory and cardiopulmonary diseases and acid rain [10]. At present, the refineries rely on the hydrodesulphurization to remove sulphur which operates at high temperature $\left(200{ }^{\circ} \mathrm{C}\right.$ to $425^{\circ} \mathrm{C}$ ) and pressure (1-18MPa) and insufficient to remove the complex compounds [11]. Biodesulfurization (BDS) is a superb remedy for this predicament allowing the removal of sulphur from complex organo sulphur compounds using microbial potential [12]. The use of surfactants/biosurfactants in BDS process enhances the desulphurization efficiency of microbes by emulsifying the hydrocarbon substrates and desulphurized products possess the surfactant like substances $[13,14]$. Therefore, the desulphurization process helps to the formation of surfactant and the addition of surfactant facilitate the desulphurization process. The integration of these two processes would outcome the economic and eco-friendly fuel supply.

\section{Role of Surfactants in Biodesulphurization}

Since the bacteria reside in the water phase and the organosulfur compounds dissolve in organic phase, the biodesulfurization reactions occur at the interface. Therefore, the efficiency of the process depends on a sufficient oil/water contact and the transfer of organosulfur compound from the oil bulk phase to the interface [15]. The low desulfurization efficiency examined in some microbes may be attributed to failure of biocatalyst to get access on hydrophobic substrate due to limited mass transfer. A rapid growth was observed with more aqueous soluble $\mathrm{DBTO}_{2}$ as compared to less soluble DBT as sole sulfur source [16]. To alleviate this bottleneck, administration of the surfactant in the desulfurizing media is a very good practice.

The effect of various surfactants including Tween-80, Triton$100 \mathrm{X}$ and Brij-35 along with cyclodextrins was investigated on the desulfurization by Corynebacterium sp. ZD-1 and improved BDS activity was observed as compared to the activity in their absence. Tween-80 provided the best outcome with DBT mass transfer between aqueous and organic phases [17]. The increase of BDS efficiency of $R$. erythropolis 1awq with Tween-80 was employed due to lower the product inhibition by diffusing it away from the cell during the desulfurization from diesel oil [18]. The BDS process of DBT in model oil by resting cell of $P$. putida CECT5279 was improved by combination of co-solvents and surfactants. The surfactants improved the solubility of hydrophobic substrates in water by reversed micelles formation which enhanced the surface area of oil-water interface which in turn improved the transport of DBT into the cells in aqueous media [19]. The biosurfactants produced by Staphylococcus sp. LFA and B. cereus SGI were used to enhance the biodesulfurization activity of Pantoea agglomerans D23W3 and Klebsiella sp. 13T to overcome the limitation of mass transfer [20].

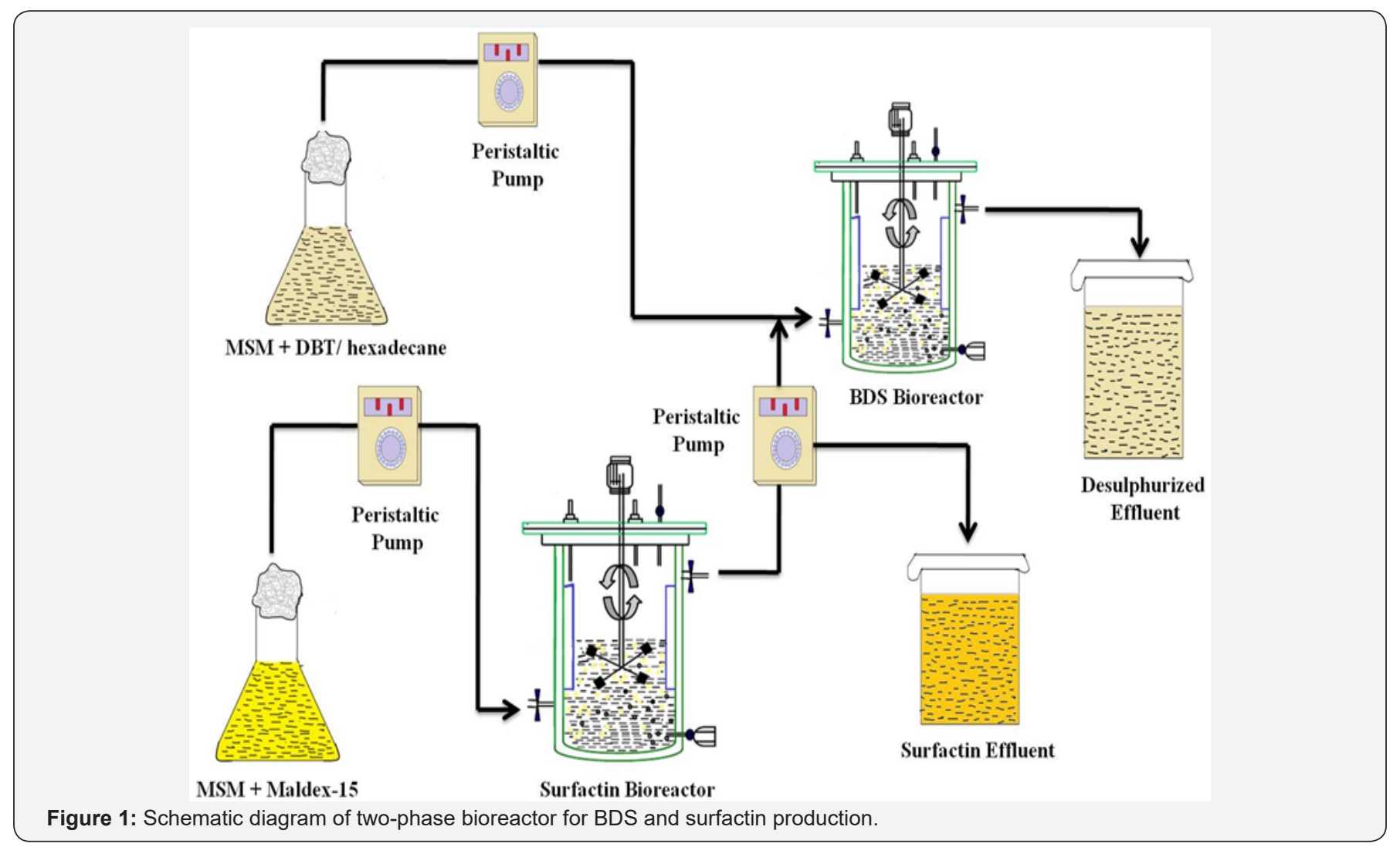


A two-phase bioreactor was fabricated by combining two vertical rotating bioreactors (Figure 1) with immobilized cells of R. erythropolis and B. subtilis. Around 98\% biodesulfurization of oil (398mg/L S) was described along with biosurfactant production $(4.8 \mathrm{~g} / \mathrm{L})$. The appropriate quantity of first bioreactor effluent embracing surfactin was blended with influent feed of other containing DBT dissolved in hexadecane and observed the enhanced BDS activity (210.5mM 2-HBP kg dcw ${ }^{-1} \mathrm{~h}^{-1}$ ) [21].

The improved desulfurization activity was attained with the use of non-ionic surfactants, Span 80 and Tween 80 [13]. DBT desulfurization by $R$. erythropolis was analyzed for mass transport step by applying biocatalyst in three forms: aqueous phase-free cells, cell aggregates and cells adhered to oil. Mass transfer limitation was found more prominent in the cell aggregates. The agitation imparting power input per volume $(\mathrm{P} / \mathrm{V})$ higher than $10,000 \mathrm{Wm}^{-3}$ and/or impeller tip speed greater than $0.67 \mathrm{~m} / \mathrm{s}$ were reported satisfactory to prevail over DBT mass transport in oil-water [22].

\section{Surfactant Production in biodesulphurization process}

Dibenzothiophene (DBT) is represented as a model compound in the crude oil. DBT biodesulphurization may take place via different pathways like kodama pathway and $4 \mathrm{~S}$ pathway [10]. The DBT degradation via kodama pathway lead to the breakdown of benzene rings lowering calorific value while $4 \mathrm{~S}$ pathway provides the way to remove sulphur from the organosulphur compounds in a specific way retaining the benzene rings intact [23]. Some researchers attempted to convert the end-products of $4 \mathrm{~S}$ pathway into commercial products resembling surfactants. To modify the process economics, the conversion of 2-HBP into hydroxyphenyl benzene sulphinate was studied to generate linear alkylbenzene sulphonates like surfactant which also increased the desulfurization rates [24]. In 1999, a patent was granted to Lange and his team providing detailed information on the synthesis of surfactants from the penultimate product of specific $4 \mathrm{~S}$ pathway (Figure 2). Transformation was executed at hydroxyl group to synthesize esters or by alkylation of the ring. The side chain length could be varied to create either oil- or water-soluble detergents [25]. Other marketable products include hydrotropes, phenolic resins, biocides or adhesives produced by sulfones and sulfoxides and 2-HBP is also renowned industrial biocides [26]. About $80 \%$ desulfurization of exhausted engine oil $(0.16-1.05 \% \mathrm{~S})$ in the bioreactor was studied with concomitant production of biosurfactant which consecutively facilitates the desulfurization [14]. Recently, Kilbane \& Stark [27] also demonstrated the use of $4 \mathrm{~S}$ pathway for the production of other chemicals such as surfactants, polythioesters and antibiotics. The surfactants play an important role in the recovery of entrapped oil from the reservoirs [6]. A large number of laboratory scale sand-pack tests $[5,28,29]$ and field tests $[30,31]$ have been performed to check the validity of biosurfactants for oil recovery successfully.

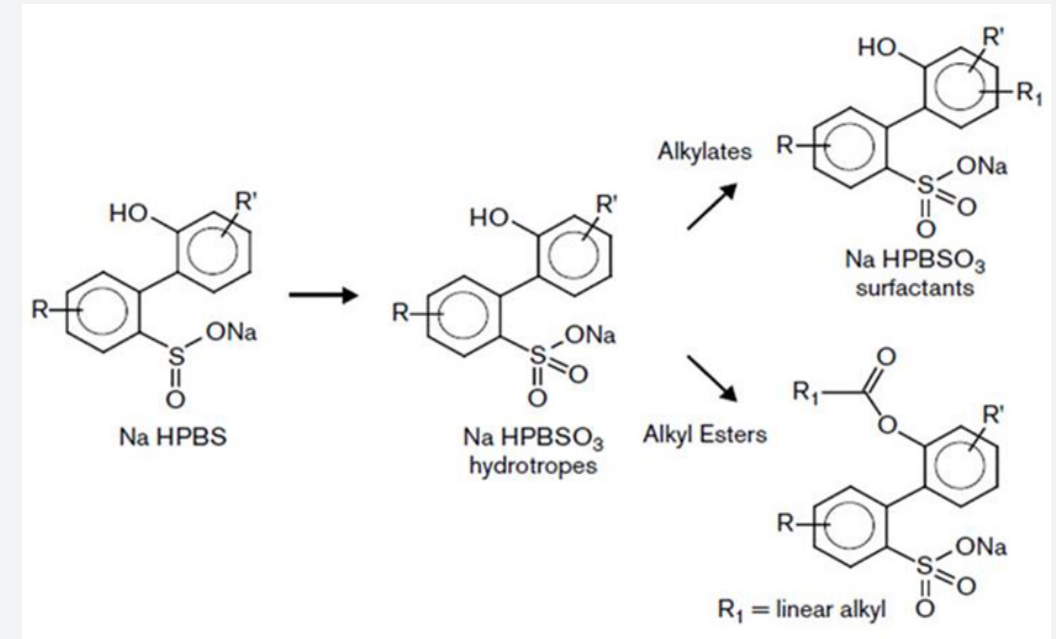

Figure 2: Conversion of HPBS (penultimate product of 4S pathway) into marketable surfactants [26].

\section{Conclusion}

The biosurfactant production and biodesulfurization represent the symbiotically integrated approach for recovery of exploitable fuel. The use of microbes and their metabolic products make the process eco-friendly and cost-effective. The biodesulphurization by $4 \mathrm{~S}$ pathway remove the sulphur resuming the calorific value of fuel with concomitant production of surfactants. In contrast, the addition of surfactants in the desulphurization process enhances the efficiency by making the hydrocarbon substrate available to the biosystem. These mutually beneficial processes open a way for refineries to provide the fuel at affordable rate. An advanced research in this integrated field may help to alleviate the energy crisis in future.

\section{References}

1. Graus W, Roglieri M, Jaworski P, Alberio L, Worrell E (2011) The promise of carbon capture and storage: evaluating the capture-readiness of new EU fossil fuel power plants. Climate Policy 11(1): 789-812.

2. Shibulal B, Al-Bahry SN, Al-Wahaibi YM, Elshafie AE, Al-Bemani AS, et al. (2014) Microbial Enhanced Heavy Oil Recovery by the Aid of 
Inhabitant Spore-Forming Bacteria: An Insight Review. Sci World J 2014(2014): 1-12.

3. Hall C, Tharakan P, Hallock J, Cleveland C, Jefferson M (2003) Hydrocarbons and the evolution of human culture. Nature 426(6964): 318-322.

4. Khire JM (2010) Bacterial Biosurfactants and their Role in Microbial Enhanced Oil Recovery (MEOR). Adv Exp Med Biol 672: 146-157.

5. Gudina EJ, Pereira JFB, Costa R, Coutinho JAP, Teixeira TA, et al. (2013) Biosurfactants-producing and oil-degrading Bacillus subtilis strains enhance oil recovery in laboratory sand-pack columns. J Hazardous Mater 261: 106-113.

6. Zhao F, Zhang J, Shi R, Han S, Ma F, et al. (2015) Production of biosurfactant by a Pseudomonas aeruginosa isolate and its applicability to in situ microbial enhanced oil recovery under anoxic conditions. RSC Adv 5: 36044-36050.

7. Hamzah A, Sabturani N, Radiman S (2013) Screening and Optimization of Biosurfactant Production by the Hydrocarbon-degrading Bacteria. Sains Malaysiana 42(5): 615-623.

8. Pereira JFB, Gudina E, Costa R, Vitorino R, Teixeira J, et al. (2013) Optimization and characterization of biosurfactant production by Bacillus subtilis isolates towards Microbial Enhanced Oil Recovery Applications. Fuel 111: 259-268.

9. Dobler L, Vilela LF, Almeida RV, Neves BC (2016) Rhamnolipids in perspective: gene regulatory pathways, metabolic engineering, production and technological forecasting. New Biotech 33(1): 123135.

10. Verma N, Sharma R, Kaur R (2016) Microbial Desulphurization Study of Dibenzothiophene and Crude Oil by a Soil Isolate. IJSRM Human 4(4): 133-145.

11. Khodaei B, Sobati MA, Shahhosseini S (2016) Optimization of ultrasound-assisted oxidative desulfurization of high sulfur kerosene using response surface methodology (RSM). Clean Techn Environ Policy 1(8).

12. Sousa SF, Sousa JF, Barbosa AC, Ferreira CE, Neves RP, et al. (2016) Improving the biodesulfurization of crude oil and derivatives: $\mathrm{A}$ QM/MM investigation of the catalytic mechanism of NADH-FMN Oxidoreductase (DszD). J Phys Chem 120(7): 5300-5306.

13. Derikvand P, Etemadifar Z (2014) Improvement of biodesulfurization rate of alginate immobilized Rhodococcus erythropolis R1. Jundishapur J Microbiol 7(3): e9123.

14. Marcelis CLM, Leeuwen MV, Polderman HG, Janssen AJH, Lettinga G (2003) Model description of dibenzothiophene mass transfer in oil/ water dispersions with respect to biodesulfurization. Biochem Eng J 16(3): 253-264.

15. Setti L, Pifferi PG, Lanzarini G (1994) Diffusion as a rate controlling step in heavy oil biodesulfurization process. Fuel Process Technol 40(2-3): 311-317.

16. Miao-dong W, Wei L, Yao S, Da-hui W, Hai F (2006) Effects of surfactant on biodesulfurization by Corynebacterium sp. ZD-1 in the presence of organic phase. J Zhejiang Uni Sci A 7(Suppl 2): 371-375.
17. Feng J, Zeng Y, Ma C, Cai X, Zhang Q et al. (2006) The surfactant Tween 80 enhances biodesulfurization. Appl Environ Microbiol 72(11): 73907393.

18. Aguila RAD, Boltes K, Leton P, Rodriguez RR, Perdigon JA, et al. (2007) Biodesulfurization of DBT in model oil by resting cell of Pseudomonas putida CECT5279: Process enhancement. In: Proceedings of European Congress of Chemical Engineering (ECCE-6), Copenhagen.

19. Agarwal P, Sharma DK (2010) Comparative studies on the biodesulfurization of crude oil with other desulfurization techniques and deep desulfurization through integrated processes. Energy Fuels 24(1): 518-524.

20. Amin GA, Bazaid SA, El-Halim MA (2013) Two-stage immobilized cell bioreactor with Bacillus subtilis and Rhodococcus erythropolis for the simultaneous production of biosurfactant and biodesulfurization of model oil. Petro Sci Technol 31(21): 2250-2257.

21. Abin-Fuentes A, Leung JC, Mohamed ME, Wang DIC, Prather KLJ (2014) Rate-limiting step analysis of the microbial desulfurization of dibenzothiophene in a model oil system. Biotechnol Bioeng 111(5): 876-884.

22. Soleimani M, Bassi M, Margaritis A (2007) Biodesulfurization of refractory organic sulfur compounds in fossil fuels. Biotechnol Adv 25(6): 570-596.

23. Pacheco MA, Lange EA, Pienkos PT, Yu LQ, Rouse MP, et al. (1999) Recent advances in biodesulfurization of diesel fuel. In: National Petrochemical and Refiners Association, Annual Meeting, San Antonio, Texas, USA, pp. 99-27.

24. Lange E, Lin Q Nielsen K, Dooyema C (1999) Surfactants derived from 2-(2-hydroxyphenyl) benzenesulfinate and alkyl-substituted derivatives, US.

25. Monticello DJ (2000) Biodesulfurization and the upgrading of petroleum distillates. Curr Opin Biotechnol 11(6): 540-546.

26. Bandyopadhyay S, Chowdhury R, Bhattacharjee C (2014) Production of biosurfactants through biodesulfurization of spent engine oil - an experimental study. Green Chem Lett Rev 7(3): 288-295.

27. Kilbane JJ, Stark B (2016) Biodesulfurization: a model system for microbial physiology research. World J Microbiol Biotechnol 32(8): 137.

28. Okpokwasili GC, Ibiene AA (2006) Enhancement of recovery of residual oil using a biosurfactant slug. Afr J Biotechnol 5(5): 453-456.

29. Qazi MA, Subnha M, Fatima N, Ali MI, Ahmed S (2013) Role of Biosurfactant Produced By Fusarium sp. BS-8 in Enhanced Oil Recovery (EOR) through Sand Pack Column. Int J Biosci Biochem Bioinforms 3(6): 598-604.

30. Jinfeng L, Lijun M, Bozhong M, Rulin L, Fangtian N, et al. (2005) The field pilot of microbial enhanced oil recovery in a high temperature petroleum reservoir. J Pet Sci Eng 48(3-4): 265-271.

31.Xiaolin W, Zhaowei H, Xumou D, Wei L, Rui W, et al. (2012) The Application of Microbial Enhanced Oil Recovery in Chaoyanggou Daqing Low-Permeability Oilfield. The Open Pet Eng J 5: 118-123. 


\section{Your next submission with Juniper Publishers} will reach you the below assets

- Quality Editorial service

- Swift Peer Review

- Reprints availability

- E-prints Service

- Manuscript Podcast for convenient understanding

- Global attainment for your research

- Manuscript accessibility in different formats ( Pdf, E-pub, Full Text, Audio)

- Unceasing customer service

Track the below URL for one-step submission https://juniperpublishers.com/online-submission.php 